\title{
Discrimination and Hate: Over-Criminalization or New Normativity?
}

\author{
Charis Papacharalambous ${ }^{1}$ \\ ${ }^{1}$ Dept. of Law, University of Cyprus, Nicosia, Cyprus \\ Correspondence: Charis Papacharalambous, Dept. of Law, Faculty of Economics \& Management, University of \\ Cyprus, University Avenue 1, 2109, Aglantzia, Nicosia, Cyprus. Tel: 3-572-289-2927. E-mail: \\ papacha@ucy.ac.cy
}

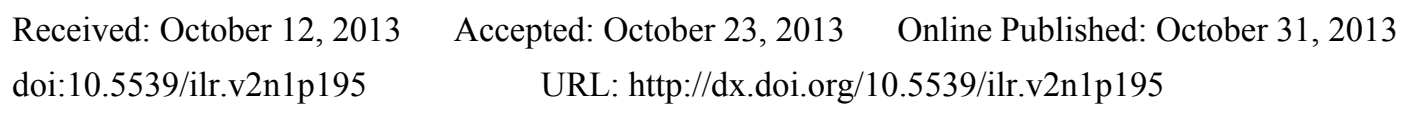

\begin{abstract}
Criminal legislation against hate speech is controversial. Main objections against such legislation refer to primacy of freedom of speech, the disproportion of the penal reaction and reservations as to the effectiveness of penal control. On the other hand, repression of hate speech seems well founded since a serious harm or at least a significant offense can be traced in such conduct. This paper argues in favor of an extensive and holistic incrimination of hate speech. Points of departure are a normative rather than naturalistic conception of harm, the connection to democratic militancy as legitimacy base of the respective criminal law control, and the abandonment of a full-fledged liberalism as this is displayed through the US paradigm as to dealing with hate speech. It is also argued that this standpoint fits better in a proper doctrinal frame concerning hate speech and discriminatory conduct. In this regard as certain traits of a proper criminal reaction to hate speech are discerned the group based legal nature of the insulting behavior, the preventive orientation of the criminal law system, especially the conception of hate speech acts as inchoate offences, the limitations as to accepting error of facts objections of the defendant, and the criminal significance of the perpetrator's 'animus', from which the very harmfulness of the conduct cannot be separated. As conclusion it is submitted that a 'maximum' criminal law against hate is needed expressing the normative primacy of democracy over abstract and negative 'freedom'.
\end{abstract}

Keywords: abstract endangerment, communitarianism, democratic militancy, First Amendment, group-based crimes, hate speech, holism, human dignity, inchoate offences, liberalism, normativism, offense principle, prevention, public order, republicanism, reputation

\section{Introduction}

Hate crime laws present a new paradigm in criminal law: they require incrimination of civil and human rights violations. Their militant nature undermines the traditional inflexibility of 'pro reo' and 'pro libertate' axioms in criminal law. They also represent a holistic incrimination approach as they should cover (according to the definition of "hate" one chooses) every form of relevant behavior, conceived of as a part of an organic whole (Note 1). Actually, hate crimes are in this regard a candidate for a methodology which has been (as allegedly representing epistemologically a version of 'organicism' and politically a version of 'totalitarianism') the target of critique in Popper's "Poverty of Historicism" (Popper, 2005: 63-5 [=Chapter I.7], 132-53 [=Chapter III.23-4]). Finally, hate crimes laws found liability in a primarily subjective mode (i.e. on the fact that the perpetrator is motivated by prejudice). A good example is s. 28(1) of the 1998 UK Crime and Disorder Act, whereby is crucial either that racial hostility was demonstrated during the commission of an offence or that the offence was motivated by such hostility.

All this has been exposed to a steady critique. It is argued that criminal legislation against hate crimes can tentatively become purely symbolic, satisfying ideological and media needs through law rhetoric, which can obliquely enhance or spread societal divisions and prejudices, while in parallel, the argument continues, empirical verification of the necessity for hate crimes laws is to significant degree lacking (Jacobs \& Potter, 2001: 65-91, 130-44). Further, hate crime laws seem to infringe on constitutional rights, especially free speech, by punishing more severely not the conduct based on the bigot's view but merely and preemptively the bigot's view itself producing thus the so called "chilling effect" of the respective law restrictions onto the right (Jacobs \& Potter, 2001: 111-29). Not least, it is also said that such legislation prepares difficulties to judges and prosecutors, makes police work more perplexed and turns, by using the prison system, counterproductive because it is this system itself that generates bias-based attitudes (Jacobs \& Potter, 2001: 92-110). 


\section{The Dilemmatic Stand of the Reaction of the Democratic Legal Systems in the West So Far}

Through all this the courts are very often confronted with a real mess. The US Supreme Court decisions R.A.V.v. City of St. Paul (1992) and Virginia v. Black (2003) are outstanding in this respect: on the one hand they try to conserve the free speech field as wide as possible, extending it also to speech forms which remain constitutionally unprotected in principle (the respective 'categorization method' is being made thematic below); on the other, they try to deal with the incrimination requirement by recurring to labels such as "virulence", criminally relevant "secondary effects of the speech" or "compelling state interest" in disavowing certain opinions or teachings as false or merely offending (Christou, 2007: 94-8, 204; see on this case law also Weinstein, 2010b: 84-8; Jacobs \& Potter, 2001: 121-9). One has to bear in mind that both decisions have been issued on cases of Klan or Klan-like burnings of wooden crosses in the garden of Afro-American family houses (see on this case-law also Heyman, 2010: 164 footnote 27).

In this framework it is hardly possible to maintain a sound distinction between (marginally still allowed) content-based and viewpoint-based laws against hate conduct. The first incriminate the message conveyed as per se violating legal interests; insofar these laws constitute principally already illegitimate speech regulations in that they surpass either the indirect act prohibitions or the 'pure speech' restrictions concerning circumstances of the pronouncement ('content neutral speech regulations'), but they are still held independent from the viewpoint underlying the message. The laws of this second category are namely laws directly incriminating such underlying views and are therefore considered as pure censorship (see on all these distinctions in the US doctrine, Christou, 2007: 89-93). Worse than this blurring of boundaries is the fact that hate crime has totally fallen out of sight here, because there is no way to combat it without exactly involving viewpoints in the criminal law (see especially on this critical point Christou, 2007: 98-9)! This is another mode of saying, as we will see further on below, that the word is the harm, that these notions are in hate speech inseparable from one another (whereas in hate 'crimes' in the strict sense the severity of hate conduct is extremely legible in an autonomously occurring result: Levin, 1999: 11-9).

As it is well argued, hate speech causes harm not only by directly traumatizing target group victims in a way analogous to causing short term effects on vulnerable victims through abusive conduct, but also by indirectly promoting a social environment of inequality and (looming or exercised) violence (Sumner, 2010: 207-11). To be admitted is that the more remote the incriminated conduct is from the real perpetration of a hate crime, the more illegitimate becomes this as an inchoate crime; if instigation presupposes a primary act and incitement is a legitimate inchoate form of crime, provisions generally incriminating promotion or dissemination of hatred lose any linkage to a criminal conduct, as long as "hatred" is a feeling, that is not criminal in itself (Sumner 2010: 212-20; Weinstein 2010a: 53-55). Given the abstractly endangering nature of hate speech though, it should be possible for a democratic (not absolutely and exclusively 'liberal') state to recur to such 'doubly inchoate' conduct not only for symbolic reasons, but by taking very seriously under consideration the need for preemptive reaction to hate speech due to the latter's characteristics to be below analyzed.

\section{The Main Forms of Dealing with Hate through Criminal Law}

The embarrassment hate crime laws prepare to the criminal law system is apparent in that all modes of traditional doctrinal attempts to deal with it must fail. One can discern three of them:

\subsection{Violation of Person's Reputation?}

The connection of hate with honor or reputation violation is the first one. The first problem here is that one is forced to affirm the construct of "group libel" and insofar to accordingly transform the individual-based conception of harm which in general is traditionally ascribed to libel. A second problem arises from the fact that thus one seems to promote identity politics in favor of collective entities which is strongly debated in the fields of constitutional law and liberal political theory. For the majority of the academics in the US the only decision favoring group libel laws, the Beauharnais v. Illinois from 1952, a case of white suprematist propaganda, has been revised (Christou, 2007: 161-215; Weinstein 2010a: 58-60; Weinstein 2010b: 87-8; on the above as well as to the entanglement of identity politics with symbolic criminal legislation, see Jacobs \& Potter, 2001: 65-78, 114-7, 130-44; cf. though the well known differentiated approach of conceding the existence of rights related to collective identities within a liberal political frame, supported by Kymlicka 1996: passim, and especially chapters 2-4, 6-9). Further, and especially concerning the common law tradition, more specifically the US law, there is no such thing as "honor", which can be identified in the continental criminal law; to be protected is rather the reputation understood as "market value", the damage of which can be recovered through tort law compensation. Besides, this can be achieved only under the terms of the critical statement being false and done with actual malice (Christou, 2007: 125-30, 141-6, 154, 160-1). After N. Y. Times v. Sullivan, the US Supreme 
Court made even libel laws dependent upon more demanding scrutiny requirements, thus 'constitutionalizing' them too (Christou, 2007: 155-60). Finally, defamation is criminalized only as long as it constitutes a public order offence; as to the rest, hate speech is considered as extreme political expression and thus in the US principally protected through the First Amendment: according to the "strict scrutiny" procedure the possibility of granting constitutionality to criminal law restrictions of free speech is almost equal to null (Note 2). At a European level, however, the recognition of the group libel through hate speech is obvious throughout the recent case law of the European Court of Human Rights (henceforth: ECtHR).

So we have at a more universal level a clear case of ambiguous treatment in identifying hate with libel. Clear is of course that the ECtHR treats extreme speech especially then more austerely when associations or parties are active; this is so because of the danger for others' rights or the public order their organizational structure represents, see Christou, 2007: 372, 375-6; see also Hare, 2010a: 72-4).

\subsection{Profound Assault on Dignity? A Crux for Liberalism}

A second alternative is the connection of hate crime with violation of human dignity. In the civil law tradition (e.g. in the German criminal law) one could uncover a stream of legal thought strongly affirming an axiological concept of dignity upon which a distinction between, let's say, "deep personhood" and "mere" personality in the sense of exerting social roles is based; according to this distinction hate crime can be more clearly shown to be a violation of this deep substrate of the person over which one cannot dispose (ethnicity, biologically determined capabilities, sexual orientation and the like). Such offences especially committed in public deserve punishment in the spirit of this tradition. As to the rest one can recur to the general civil and criminal laws or to the eventual specific anti-discrimination laws (see respectively: Christou, 2007: 216-34, 244-7).

In contradistinction to this the US law promotes criminalization of discrimination in the commercial private sector (except contracts or agreements affecting highly personal relations like hiring a governess or getting married); this is e.g. the case with prohibitions of entry to people of color. On the other hand this tradition dismisses restrictions of hate speech even when the latter is publicly expressed. No metaphysical dignity is recognized and any approach of the person going beyond the notion of a procedurally intact claimant connotes for many liberals ideals of solidarity suspect of crypto-communitarian preoccupations (Christou, 2007: 211-5, 234-8, 241, 244-7).

The only way to bring someone to justice is then to have a case where an "act" instead of mere "speech" is at stake. This is the famous act-speech dichotomy established with the Supreme Court decision in Chaplinsky v. N. Hampshire from 1942 and its "categorization approach", according to which obscene, profane or extremely aggressive speech has been subtracted from First Amendment protection (in the Court case a Jehovah witness has called a policeman "god damned fascist" and "racketeer"). This can be of no concern as long as a result or at least a conduct hate crime has been committed; in the case of hate speech though the victims remain without protection in the framework of a (considered as "free") "marketplace of ideas", the "firstness" of which is inflexibly presupposed on the grounds of an abstract deontology based on an unreflectively assumed methodological individualism: whenever individuals are not endangered the speech runs free, principally without context-dependent balancing, as long as only a 'definitional' balancing is held as proper (Christou, 2007: 51-74, 133-9; a recent exhaustive review of the characteristics of the 'marketplace of ideas' topic, see in Salton, 2012: 1-6). This 'marketplace', as Israel very correctly notes,

"[...] has become a poor regulator. When a speech issue becomes politicized there is no intellectual free trade, but an intense competition of sound bites and phrases calculated to catch the attention of a bored public emerges. The press has an appetite for the other side".

One tries to heal this in attempting to trace some harm behind the speech if the latter can be conceived of as intra-linguistic effect, namely as inherent in the speech and occurring through it. This is embracing John Austin's "speech act" theory. According to this the victim of hate speech is 'illocutionary' disabled, is, in a sense, forcibly "silenced" in his/her very right to behave freely and spontaneously. If criminal law, the argument continues, punishes 'perlocutionary' effects, namely extra-linguistic effects of the speech, as is the case with instigation or incitement, there is reason to punish also the illocutions as something less than incitement but enough more than mere words (Christou, 2007: 238-43). One could add to this also, that in any case what is at stake as to hate speech is not the epistemic aspect, the truthfulness or not of "facts" raised by a pronouncement, but the very moral/ethical aspect of its normative unacceptability, an aspect more suitably envisaged by a rather 'positive' (normatively disciplined, even if still concretely- ethically not binding) than 'negative' (morally neutral) account of freedom rights (Christou, 2007: 38-9, 103-5). 
The problem with this is that for the enactment of criminal law sanctions the judgment should be secure, that is, based on a clear-cut distinction between free and harmful conduct; wherever the judgment is controversial as to whether what has been done is harm, then the in dubio principle prevails. We could resist this by widening the protection scope up to the "offense principle" (Note 3). We could namely abandon the requirement of having a "palpable" violation for punishing hate. That hate speech violates fundamental rights is in any case well established theoretically (see a well founded approach on this, focusing on recognition denial through hate, in Heyman, 2010: 165-9; see also Christou, 2007: 186-7 and at footnote 453). In most cases of hate speech the very meaning of it is offending, it redeems no social value and counter-arguing against legitimizes it (very lucidly on these aspects Israel, 1999: 106-9). This discussion is, of course, still open: Owen Fiss assumes a harm caused by hate speech, and Joseph Raz also argues that toleration of hate speech means primarily its acceptance, which is unbearable for a democratic state. Others react differently, for instance R. Dworkin senses concessions to "paternalism" behind these arguments (see on these standpoints, Christou, 2007: 105-7, 243, 246-7, 381-2).

It seems though all the more that liberalism must deny normatively well established rights if it insists in being strictly coherent. So, it cannot guarantee gender equality and protection from domestic violence if religious freedom is granted a space within which women are clearly disempowered (Evans, 2010: 364, 368-74). More fundamentally seen, the very implication of modern liberalism that legitimacy can only be the outcome of a deliberative procedure, whereby the best argument shall prevail, turns completely idealistic; its Habermasian/Rulsian impetus sidesteps the very meaning of value-laden controversies, devalues their passionate nature through over-rationalizing the conflict of beliefs and imposes the US particularity of autonomy's and individual freedom's glorification upon cultures structured otherwise (see on this and especially the Israeli-US cultural/legal differentiation Reichman, 2010: 336-7, 342-5, 350-2; analogously see, on the US 'individualism' vs. German 'republican communitarianism' differentiation, Christou, 2007: 41-3). Even sociologically one can discern in the US an deeply rooted idiosyncratic culture of aggressively displaying disrespect to Eurocentric hegemonic elite norms, which produces a populist 'leveling down' effect, so contrary to the European 'elitist' normativism (see on this view of J. Q. Whitman indicatively e.g. Post, 2010: 137-8; Christou, 2007: 114-6).

Unless, we conceive of liberalism not in the sense of mere agnostic toleration whereby free speech serves the wider social benefits, but in a principled sense, whereby free speech is a non-instrumental value in itself and then capable of combating adverse values like religious over-sensitivity. Insofar, and in conformity with an according cosmopolitan interpretation of article 10 ECHR, freedom of (even emotively charged) speech outbalances a supposed 'right not to be religiously offended' (Cram, 2010: 316-27; analogously favoring a non-instrumental value of free speech also Weinstein, 2010a: 60-1). On the other hand, the value is nonetheless inherently 'thin' as long as normative expectancies are concerned, whereas the 'communitarian' alternative looks out rather over-'thick' as long as liberties and rights are concerned: even if value-laden, liberalism is still too moral-oriented to form something more effective than the complementary flip-side of an equally too much concrete ethics-oriented communitarian stance. What lacks both is democratic militancy. With regard to such kind of argument one cannot save liberalism by trying to re-integrate extremist speech into an over-inclusive liberal polity based on "agonistic respect" backed by a discourse ethics lying principally outside the legal-repressive paradigm and deliberatively proceeding so that extremism may function as collaterally benefiting liberalism in making the latter's legitimacy deficits publicly thematic (cf. this sympathetic attempt by Malik, 2010: 107-20).

Also the attempt to save liberalism through Robert Post's theory on 'democratic legitimacy' is failing: where racist speech offends a group, there are still not all citizens 'silenced' or 'alienated', as this theory would require in order to let hate speech be censored. Protection succumbs thus, practically, again to toleration, since it tacitly presupposes that only peculiar individuals may be candidate offenders; the public conflict turns surreptitiously 'reprivatized' (cf. differently Cram, 2010: 327-30; similarly in favor of boundless freedom of expression on liberalistic-pragmatic grounds, Baker, 2010: passim and at 146, 150-7). At least, such theoretical patterns, allegedly displaying the 'perennial essence' of a 'polity', turn easily abstract-essentialist or a-historic (Heinze, 2010b: 190-203). In case one fills liberalism with more thick values, one comes up with non-liberal consequences: if, which is correct, the First Amendment philosophy is to be interpreted as primarily 'other-rights-based', i.e. not as an absolute value, then the path opens even for the incrimination of private hate speech, because it simply negates the rights of others and insofar it isn't a right itself any more (Heyman, 2010: 163-4). As Heyman writes:

"[T] he balancing of rights is subject to a crucial constraint; an asserted right can derive no value from its negation of another right. If rights like personal security, personality, and equality have positive value, the negation of those rights cannot also have such value" (Heyman, 2010: at 164, footnote 25). 
Fine, but then the liberalist edge is cut, and this is the crucial point that Heyman's view uncovers! The exclusion of the hate speech perpetrators is suggested exactly in the manner that common crime is usually excluded, that is, without legitimacy concerns. It is the peculiarity of hate speech that liberalist accounts risk to miss. They fail to account for the fact that hate speech is not speech in the meaning of a contribution to a non-coerced dialogue, since it, by its very essence, blocks the very possibility of beginning any kind of deliberation. Insofar it is not exertion of a right but a systematic and purposeful display of the intent to imminently damage deliberation through rights negation. Far from searching in 'unconventional' ways for truth, hate speech destroys the elementary conditions for pursuing truth. If then political discourse is meant as promotion of emancipation and formation of social and interpersonal relations in a democratic manner, hate speech is not a political attitude (see respectively on all these aspects the lucid text of Heyman, 2010: 169-77).

No other meaning can be given to provisions explicitly excluding racism and anti-Semitism from political discourse, like those of articles 19 para 3 and 20 para 2 of the 1966 International Covenant on Civil and Political Rights (admitted by Hare, 2010a: 70-1, 76); and it is only consistent to supporting the US one-sidedness in protecting free speech when it is argued that the European standards do not serve enough the freedom of extremists, anti-Semitists and racists (cf. this anti-European, hard core 'common law' approach in Hare, 2010a: 78-80). And, of course, no argument in favor of liberalism can be made out of abusively referring to clear cases of politically motivated selectivity. There, certain contributions to the political arena are excluded and remain unprotected merely due to their 'unconventional' nature, disliked by the establishment, as the notorious Dennis $v$. US (1951) has disappointingly shown (see e.g. the respective admission of Weinstein, 2010a: 42-3; Weinstein, 2010b: 91).

On the other hand it must be said in favor of another position Post has maintained, that hate speech is, this time, more accurately discerned. He argues namely correctly that treating hate speech as endangerment is incorrect. Hate speech is not dangerous like incitement is, it cannot be dealt with as more or less imminent ('clear and present') danger, it is not principally punished for what it may engender (even if empirically this may be the case); opposite to this, hate speech is principally punished, Post continues, because it violates essential social norms of civility and respect, because it is already a harm insofar and not merely a risk for letting something else occur (Post, 2010: 129-30, 134-6; cf. to this Weistein, 2010a: 55-8, rather identifying, according to the common sense, civility with 'formal politeness', which, of course, is not absolutely worthy of protecting). The experience of causal connection between speech and violence, as Post puts it:

"[U]nderscores the subjective sense of disorder that arises whenever social norms of propriety or civility are violated $[\ldots]$ But hate speech regulation is distinctive in that it seeks to repress speech merely because it has 'the tendency' to produce violence or disorder. Law that seeks to suppress speech with this 'tendency' is in reality law that seeks to suppress violations of essential social norms" (Post, 2010: at 136, emphases added).

This approach is followed here as long as it both stresses the specific harmfulness of hate speech and the inadequacy of treating it as a security or public order issue (Note 4). But let us see this last option in more detail immediately below.

\subsection{The Shortcomings of the 'Public Order' Viewpoint}

There is finally a third option: the connection of hate crime with security interests. One recurs here to Justice Holmes' formula of a "clear and present danger" emanating from the Supreme Courts' case law during the intra-war period. Modified (through the interpretations of Justices Learned Hand and Brandeis) from context-dependent judging towards 'classic' incitement incrimination, the test found its best application in Brandenburg v. Ohio (1969). However, this option of solving the problem is futile because such rubrics are destined to deal with crimes against the state (such as treason or espionage), which are totally alien to hate crimes (see also Christou, 2007: 295-303).

Public order has surfaced also as legal interest violated by hate conduct. This is largely the case in Germany. Notwithstanding the risk that public order may be, through the respective legislation and case law there, so overpowered that it may paternalistically promote pure loyalty instead of autonomously engendered respect for the Constitution, the German solution is basically rightly oriented: undifferentiated formal-negative protection of free speech is subjected to a more ethics-based conception safeguarding the material conditions of moral autonomy and thus propelling the latter (cf., with critical overtones, Christou, 2007: 248-87, especially at 257, 262-3, 276-82; in favor of the German model specifically as to de-legitimizing and combating exclusively neo-nazism, see Papacharalambous, 1991: 287-9, 350-1, with further references). Analogous is the Greek anti-hate legislation (Christou, 2007: 352). Also the British legislative development from 2006 to 2008 
concerning the abolition of blasphemy and the introduction of 'incitement to religious hatred' aims, in a more functionalistic manner, at security purposes, replacing an outmoded and content-based criminal law prohibition, deemed as oppressive. That the public order protection tends through this development, though, to produce a kind of 'normative inflation' by multiplying punishable incitement beyond the well established core of racial hatred is a problem already noticed: as to be protected are also identified, for example, religious groups which are competitive among themselves, well equipped as to budget and logistics, and publicly influential, thus not much in need of protection if compared with vulnerable racism victims (see e.g. Hare, 2010b: 296-310). The French paternalist model of guiding society through the state is another variation of promoting security interests. Apart from the involvement of the executive for dissolving dangerous associations (which insofar is similar to the German model of organizations dissolution) at an administrative law level (see e.g. Mbongo, 2010: 222, 226-7), the criminal law system establishes a very widened net of provisions, which to a significant degree goes very far beyond security interests, in that it protects also human dignity and (group) reputation against hate speech even when a speech has been not publicly pronounced (Mbongo, 2010: 227-8).

Similar is the construct of the so called "fighting words" in the US, which nonetheless has been practically dismissed by the Supreme Court jurisprudence because of "vagueness" or "over-breadth". As to hate speech the construct seems in its insistence on close interpersonal communication rather outmoded and, due to the weak position of hate speech vulnerable victims, rather misplaced, thus merely symbolically declaring the legal disapproval of provocative conduct in general (Christou, 2007: 288-95). Besides, even this construct has not healed the paradox of hate speech laws conceived of in a static and abstract manner: non-extension of hate laws to ever new categories of protected persons or groups means discrimination, whereas such extension censors massively (Heinze, 2010a: passim, who pleads for the abolition of hate laws within "longstanding, stable, and prosperous democracies", totally thus soothing and neutering hate laws as politically keen laws: at 285; cf., opposite to this approach, the political nature of not adequately applying hate laws within a racism-friendly societal environment, observed by Molnar, 2010, passim, as to the stance of official institutions in Hungary).

A progress in the field brought the so called "true threats" doctrine. Even if a true threat requires a speaker-based approach, it can guarantee punishment to a significant degree by using criteria of "reasonableness"; helpful is also the fact that differently from incitement and instead of requiring an interpersonal and causal conduct true threat lets a communication through the net and the ascription of a purely "normative" causation suffice. Virginia v. Black (2003) has mainly given the doctrine its contours, without though closing all possible loopholes as a holistic incrimination of hate speech would have it. However, true threats can principally allow, letting normative criteria suffice and not requiring naturalistic causation in the strict sense, capture also illocutions beyond the perlocutionary pronouncements, an issue already earlier hinted at as crucial (see above under subchapter 3.2; Christou, 2007: 303-21, 325-6, 369). Along these lines the incrimination of "threat" as such in the Cypriot Penal Code (art. 91 A introduced through L. 56(I)/2001), namely of terrorizing or intimidating the victim by menacing with the commission of a violent act, was a development in the right direction.

\section{Concluding from the Above on the Quintessence of Hate Speech}

Be it as it may, the whole premise of punishing hate crime by omitting to accurately and comprehensively target it, is misplaced. The possibilities state instances have in misusing hate laws based on security interests for reactionary purposes let aside (see on such misuses e.g. Malik, 2010: 99-105), such laws turn totally oblivious of the new normative underpinnings of the hate crime prohibitions. Let's think what ought this all to be about: we should recall Nazi laws against Jews and opponents; the international crimes as they have been formed from Nuremberg to the ICC; cases like the disputable old decision of Illinois Supreme Court in re: Village of Skokie v. NSP of America (1978); further, harassment and domestic violence or the social toleration of widespread commission of heinous organized crimes like trafficking in humans escorted by the perpetuation of an incrimination model as totally outmoded as the one based on "individual responsibility".

What is common in these types of conduct and in the respective legal and judicial reaction against them?

Firstly, we have basically to do with group-based crimes. Not the individual but a common characteristic of it, shared with others in a way the individual cannot dispose of, is the target of the attack, hence the imminence and the tendency of spreading inherent in the conduct.

Secondly, the criminal law reaction against discrimination should be per se preventive and pro-active by principally allowing liability to be established without requiring strict application of causation terms or of the correspondence principle between actus reus and mens rea; that thus some concessions to a de facto reversal of the burden of proof are made, is to be admitted, but this cannot put in doubt the legitimacy of abstract 
endangerment as an in general well established doctrinal feature, able to apply also here (Note 5). Prevention will do especially where hate crime and racism turn all the more 'terroristic', like in the US (see respectively the historical account attempted in this regard by Petrosino, 1999: passim; as to Afro-Americans see also Torres, 1999: passim). In Cyprus the anti-discrimination laws enacted in 2002 and 2004, aimed at the necessary harmonization with the respective EU Directives, follow this pattern in establishing reversal of burden of proof (outside criminal proceedings), affirmative action, and administrative monitoring authorities; especially to be mentioned is L. 42(I)/2004 granting enhanced competences to the Ombudsman Against Racial Discrimination.

Thirdly, the perpetrator's error as to the qualifications of the victim has to be dealt with as "error in persona" and not as genuine error of fact, which could negate criminal intent;

Fourthly, the motives become crucial instead of "intention" (being technically understood as voluntariness plus knowledge plus willfulness), because fighting against discrimination and hate means rather reaffirmation of law aims through an entire punishment of "mere guilty mind" externalizations without further act than traditional fragmentary sanctioning of acts (deemed to be legally, if not already morally, principally "neutral"). Insofar crucial as to hate speech is not to restrict through qualifications of mens rea requirements an allegedly wide ('complete crime type') conduct (as to this traditional restrictive legislative mode see e.g. Christou, 2007: 359) but instead to expand comprehensively incrimination of hate conceived of principally and basically as an inchoate offence. The identification of actus reus and not mes rea issues is at stake. Therefore 'mere advocacy' may be freed from punishment when (irrespective of the 'cogitationes' of the agent) one, in exerting scientific research, attacks certain groups without obviously lashing out at individuals (see e.g. Christou, 2007: 356). But it only may. A context-dependent interpretation can possibly uncover that the advocacy is actually not that much 'mere'. This is of course different from saying that individuation of penal treatment should die out; personality-based psycho-legal arguments (presented during the process as defences by the lawyers) may have their particular and non-generalizable merit (see e.g. Dunbar, 1999: 72-5) Important is that this cannot outweigh the holism of an animus-based incrimination as a principle. Therefore any argument going beyond psychopathy and aiming at (generalizable) justification or excuse should be interpreted with regard to criminal responsibility as mere "technique of neutralization" (see on such defendants' attempts e.g. Byers, Crider \& Biggers, 1999: passim). Prior to these techniques "an actus reus exists in words" (succinctly so Israel, 1999: at 107 in fine).

Fifthly, and this is narrowly connected with the previous topic, hate crime laws are militant political weapons of a democratic state and cannot be conceived of properly by reducing them to traditional crime laws. That means of course that anti-hate criminal law must be holistically constructed and construed (and consequently it must not leave loopholes of protection) but by the same token and in contradistinction to the usual criminal law paradigm it should not become "universalistic" (in the pejorative sense). The strong moral-political commitment anti-hate laws express, i.e. the democratically required protection of decency of the socially vulnerable, prevent such sublimations so common in the ideology of legalism. You cannot, for instance, label every discrimination against whatsoever a "hate act"; you can only by ridiculing anti-hate laws apply them against those counter-offending the genuine perpetrators (for instance, by labeling as hate speech the stigmatization of a racist as "racist" or "outcast"). Analogously, applying hate crime laws may be in concreto redundant (see for instance DPP v Pal [2000], where an Asian has uttered racial insults against another Asian out of anger at his previous ejection by the victim from a community centre where the latter served as caretaker). On the other hand, it was e.g. an initial mischief that in the US a 2007 Draft for a Local Law Enforcement Hate Crimes Prevention Act ('LLEHCPA'), which would have enormously facilitated prosecutorial work, has been withdrawn due to a promised presidential veto (Human Rights first, 2008: 137, 175). Finally, the Law, being conceived as a legislative response to the brutal hate-motivated murders of M. Shepard and J. Byrd, Jr. back in 1998, passed Congress on the $22^{\text {nd }}$ of October 2009, having extended bias categories under federal protection to include gender identity, sexual orientation, and disability; it has been signed into law by President Obama on the $28^{\text {th }}$ of said October (see on this history: LLEHCPA, 2009).

This leads us also to another crucial conclusion: you cannot sever the acts and purposes from the underlying system of ideas of the perpetrators. This is somehow commonplace in the human rights law doctrine. As Finnis puts it concerning religious fundamentalism, 'sharia' or 'jihad' are inseparable from a certain religion, inherent and not extraneous to it and incompatible to the secularized democracy ideal guiding the ECtHR in Refah Partisi et al. v. Turkey (2003) (Finnis, 2010: 436-41; equally as to the gender equality perspective McGoldrick, 2010: 426). As also Şahin v. Turkey (2007) (a headscarf 'hijab' prohibition case) amply shows, the ECtHR jurisdiction has often recurred to public-order considerations as to conduct and expressions held illegitimate; in such contexts the behavior need not harm, offend or exert pressure on somebody and from a strongly supported feminist point of view the anti-woman symbolism of the dress may suffice for its prohibition. Besides, the respective French 
2004 Law prohibiting the wearing of conspicuous religious insignia inside educational institutions, seems to have worked effectively even concerning the Muslim parents who preferred that their girls unveil if this was the condition that they continued going to school (McGoldrick, 2010: 410-1, 422-4). Noteworthy is also, that restrictions of overbroad anti-discrimination laws seem more persuasive if proposed in a political climate already sufficiently ensuring minorities' rights. So, if the British Hammond v. DPP (2004) case seems unbearably contradicting the older ECtHR standpoint expressed e.g. in Handyside v. UK (1976) and protecting "offending, shocking and disturbing" expressions, whereas the Swedish Supreme Court's decision in re Ake Green (2005) in favor of the Handyside spirit seems to be a finer balancing judgment, this is not unrelated to the fact that homophobic speech has become so discredited that anti-homosexual speech without a harm link may hardly be any more felt as "insulting". Insofar, the crucial point is not that much the inflexibility of 'definitional balancing' towards the virtues of proportionality thinking (cf. adversely Leigh 2010: 388-99 and simultaneously his very accurate observation of a contemporary 'mainstreaming' of homosexuality, which he aptly labels "the complete Devlinization of gay rights", at 375-7). Besides, the directness of violation of democratic values is very crucial in any event. If Hammond may exhale a spirit hostile to core free speech right, Norwood v. DPP (2003), a case resulted in conviction for placing in a flat's window a poster with anti-Islam pronouncements and picturing, may not (Weinstein, 2010a: 30-50). It may, on the contrary, display, even if one abides by the requirements of restrictive interpretation, that

"[E]xpress advocacy of policies antithetical to democracy is not a legitimate part of the public discourse by which people govern themselves and thus may be suppressed without violating the core democratic free speech principle" (Weinstein 2010a: at 48).

It must be admitted that this militant and comprehensive approach is exposed to some serious critique and that further work has to be done on the dogmatic features of "assault" or of "unprovoked random attacks" aiming at eventually achieving a coherent restraint of general and widely used incriminations of "hate", which can overburden the freedom of political communication. Conversely, no hurdles are visible in punishing certain views or specific utterances in which historically hate conduct has been crystallized, which are obviously normatively unbearable, and which offend without ever being able to further scientific discussion (an example gives the Holocaust denial in the first place). Further, why should we perfectly individualize the symbolic harm at each possible victim's psyche, when normatively a hate crime is not otherwise intelligible but as a group-based one? And finally: what does impede us to criminalize hate conduct whereas we are (normally!) not willing to allow a conduct promoting, for example, rape or pedophilic tendencies?

We have then to accept that the criminal law against hate and discrimination should by definition be maximal, not minimal. There is a good reason for all this: criminal protection of the citizens' equality status is hypocritical if the law will not contribute to the eradication of the evil's roots. Let's say it clearly: Criminal law has to take sides against the misery engendered by a market democracy becoming all the more crime-generating and immoral. Insisting on an outmoded and undifferentiated "liberalism of safeguards and balances in favor of the defendant" overlooks that in the modern criminal law doctrine individual guilt is being bypassed by an increasing focusing on "collective" forms of guilt (such as organized crime; national, trans-border and international macro-criminality; corporate crimes etc.), as well as that the old fashioned ethically colorless criminal law positivism should be progressively replaced by politically and ethically engaged criminal legislation in the framework of a "thick" democracy concept borrowing from strong republican principles, understood as full of concrete political content and not merely as tools for achieving formal "politeness" (insofar my point of departure is a strongly anti-Habermasian one; on the three democracy models, liberal, republican, and procedural-deliberative, see Christou, 2007: 331-6).

In this framework there are good reasons why also non-individualized hate speech ('abstract hate speech') is also to be incriminated. This is namely so not only because deontology is not to be interpreted necessarily from the viewpoint of the individual or because teleology indicates social or communitarian values, but also because democracy as a normatively "thick" notion is an 'ought to' and a 'telos' simultaneously in- and for-itself (cf. the theorizing on these aspects followed by Christou, 2007: 378-87). Accordingly, merely by-passing the problem of hate speech through technically inspired regulations will not do (cf. Dworkin's 'partnership democracy' in Christou, 2007: 336-8). Contrary thus to the US conception concerning dealing with hate (cf. Christou, 2007: 324), democracy precedes freedom.

The probable objection warning with an eventual "Guantánamo syndrome" fails: the latter is not the culmination of political correctness but rather the official legitimization of prejudice and hate, which is exactly what has to be fought against... 


\section{References}

Ashworth, A. (2011). The Criminal Law's Ambivalence about Outcomes. In Craft, Rowan, Kramer, H. Matthew, Reiff \& R. Mark (Eds.), Crime, Punishment, and Responsibility (pp. 159-172). Oxford UP. http://dx.doi.org/10.1093/acprof:oso/9780199592814.003.0010

Baker, C. E. (2010). Autonomy and Hate Speech. In I. Hare \& J. Weinstein (Eds.), Extreme Speech and Democracy (pp. 139-157). Oxford UP.

Byers, B., Crider, B., \& Biggers, G. (1999). Bias Crime Motivation. A Study of Hate Crime and Offender Neutralization Techniques Used Against the Amish. Journal of Contemporary Criminal Justice, 15(1), 78-96. http://dx.doi.org/10.1177/1043986299015001006

Christou, V. (2007). Die Hassrede in der verfassungsrechtlichen Diskussion, Nomos Verlag 2007. http://dx.doi.org/10.5771/9783845200583

Cram, I. (2010). The Danish Cartoons, Offensive Expression, and Democratic Legitimacy. In I. Hare \& J. Weinstein (Eds.), Extreme Speech and Democracy (pp. 311-330). Oxford UP.

Dunbar, E. (1999). Defending the Indefensible. A Critique and Analysis of Psycholegal Defense Arguments of Hate Crime Perpetrators. Journal of Contemporary Criminal Justice, 15(1), 64-77. http://dx.doi.org/10.1177/1043986299015001005

Evans, C. (2010). Religious Speech that Undermines Gender Equality. In I. Hare \& J. Weinstein (Eds.), Extreme Speech and Democracy (pp. 357-374). Oxford UP.

Feinberg, J. (1987). Offense to Others. The Moral Limits of the Criminal Law. Oxford UP

Finnis, J. (2010). Endorsing Discrimination between Faiths: A Case of Extreme Speech? In I. Hare \& J. Weinstein (Eds.), Extreme Speech and Democracy (pp. 430-441). Oxford UP.

Hare, I. (2010a). Extreme Speech Under International and Regional Human Rights Standards. In I. Hare \& J. Weinstein (Eds.), Extreme Speech and Democracy (pp. 62-80). Oxford UP.

Hare, I. (2010b). Blasphemy and Incitement to Religious Hatred: Free Speech Dogma and Doctrine. In I. Hare \& J. Weinstein (Eds.), Extreme Speech and Democracy (pp. 289-310). Oxford UP.

Heinze, E. (2010a). Cumulative Jurisprudence and Hate Speech: Sexual Orientation and Analogies to Disability, Age, and Obesity. In I. Hare \& J. Weinstein (Eds.), Extreme Speech and Democracy (pp. 263-285). Oxford UP.

Heinze, E. (2010b). Wild-West Cowboys versus Cheese-Eating Surrender Monkeys: Some Problems in Comparative Approaches to Hate Speech. i In I. Hare \& J. Weinstein (Eds.), Extreme Speech and Democracy (pp. 182-203). Oxford UP.

Herring, J. (2008). Criminal Law. Text, Cases, and Materials. Oxford UP

Heyman, S. J. (2010). Hate Speech, Public Discourse, and the First Amendment. In I. Hare \& J. Weinstein (Eds.), Extreme Speech and Democracy (pp. 158-181). Oxford UP.

Human Rights first. (2008). 2008 Hate Crime Survey. Retrieved from http://www.humanrightsfirst.org/wp-content/uploads/pdf/FD-081103-hate-crime-survey-2008.pdf

Israel, M. (1999). Hate Speech and the First Amendment. Journal of Contemporary Criminal Justice, 15(1), 97-110. http://dx.doi.org/10.1177/1043986299015001007

Jacobs, J. B., \& Potter, K. (2001). Hate Crimes. Criminal Law and Identity Politics. OUP.

Kymlicka, W. (1996). Multicultural Citizenship. A Liberal Theory of Minority Rights. Oxford: Clarendon Press. http://dx.doi.org/10.1093/0198290918.001.0001

Leigh, I. (2010). Homophobic Speech, Equality Denial, and Religious Expression In I. Hare \& J. Weinstein (Eds.), Extreme Speech and Democracy (pp. 375-399). Oxford UP.

Levin, B. (1999). Hate Crimes. Worse by Definition. Journal of Contemporary Criminal Justice, 15(1), 6-21. http://dx.doi.org/10.1177/1043986299015001002

LLEHCPA (Local Law Enforcement Hate Crimes Prevention Act). (2009). Retrieved from http://en.wikipedia.org/wiki/Matthew_Shepard_and_James_Byrd,_Jr._Hate_Crimes_Prevention_Act

MacGoldrick, D. (2010). Extreme religious Dress: Perspectives on Veiling Controversies. In I. Hare \& J. Weinstein (Eds.), Extreme Speech and Democracy (pp. 400-429). Oxford UP. 
Malik, M. (2010). Extreme Speech and Liberalism. In I. Hare \& J. Weinstein (Eds.), Extreme Speech and Democracy (pp. 96-120). Oxford UP.

Mbongo, P. (2010). Hate Speech, Extreme Speech, and Collective Defamation in French Law. In I. Hare \& J. Weinstein (Eds.), Extreme Speech and Democracy (pp. 221-236). Oxford UP.

Molnar, P. (2010). Towards Improved Law and Policy on 'Hate Speech' - The 'Clear and Present Danger' Test in Hungary. In I. Hare \& J. Weinstein (Eds.), Extreme Speech and Democracy (pp. 237-264). Oxford UP.

Papacharalambous, C. (1991). Das politische Delikt im legalistischen Rechtsstaat. Beitrag zu einer Theorie der illegalen politischen Kommunikation. P. Lang, Frankfurt a. M., Bern, N. York, Paris

Petrosino, C. (1999). Connecting the Past to the Future. Hate Crime in America. Journal of Contemporary Criminal Justice, 15(1), 22-47. http://dx.doi.org/10.1177/1043986299015001003

Popper, K. (2005). The Poverty of Historicism (translated into Greek by Ath. Samartzis). Eurasia, Athens.

Post, R. (2010). Hate Speech. In I. Hare \& J. Weinstein (Eds.), Extreme Speech and Democracy (pp. 123-138). Oxford UP.

Reichman, A. (2010). Criminalizing Religiously Offensive Satire: Free Speech, Human Dignity, and Comparative Law. In I. Hare \& J. Weinstein (Eds.), Extreme Speech and Democracy (pp. 331-354). Oxford UP.

Salton, H. T. (2012). A Godless Constitution? Faith, Politics and Speech in the Bill of Rights of the United States. International Law Research, 1(1), 1-12. http://dx.doi.org/10.5539/ilr.v1n1p1

Sumner, L. W. (2010). Incitement and the Regulation of Hate Speech in Canada: A Philosophical Analysis. In I. Hare \& J. Weinstein (Eds.), Extreme Speech and Democracy (pp. 204-220). Oxford UP.

Torres, S. (1999). Hate Crimes against African Americans. The Extent of the Problem. Journal of Contemporary Criminal Justice, 15(1), 48-63. http://dx.doi.org/10.1177/1043986299015001004

Weinstein, J. (2010a). Extreme Speech, Public Order, and Democracy: Lessons from The Masses. In I. Hare \& J. Weinstein (Eds.), Extreme Speech and Democracy (pp. 23-61). Oxford UP.

Weinstein, J. (2010b). An Overview of American Free Speech Doctrine and its Application to Extreme Speech. In I. Hare \& J. Weinstein (Eds.), Extreme Speech and Democracy (pp. 81-91). Oxford UP.

\section{Case Law}

Beauharnais v. Illinois 343 US 250 (1952)

Brandenburg v. Ohio 395 US 444 (1969)

Chaplinsky v. N. Hampshire 315 US 568 (1942)

Dennis v. US 341 US 494 (1951)

DPP v. Pal, CrimLR 756 (Divisional Court) (2000)

Hammond v. DPP, EWHC 69 (Admin.) (2004)

Handyside v. UK, ECtHR, 1 EHRR 737 (1976)

N. Y. Times v. Sullivan 376 US 254 (1964)

Norwood v. DPP, EWHC 1564 (Admin.) (2003)

Prosecutor General v. Ake Green [= Supreme Court of Sweden, Case B 1050-05, November 29 ${ }^{\text {th }}$ of 2005] (2005)

R.A.V. v. City of St. Paul, Minnesota 505 US 377 (1992)

Refah Partisi et al. v. Turkey, ECtHR, 37 EHRR 1 (Grand Chamber) (2003)

Şahin v. Turkey, ECtHR, 44 EHRR 5 (2007)

Village of Skokie v. NSP of America 373 NE 2d 21 (Ill. Supreme Court) (1978)

Virginia v. Black 538 US 343 (2003) 


\section{Notes}

Note 1. This characteristic may lead to a variety of scopes of law application and is also prone to promote a fear of crime panic (as to this see Jacobs/Potter 2001: 11-28, 45-64).

Note 2. As to the differentiations among 'strict scrutiny', 'intermediate scrutiny' (reserved for deteriorations of speech acts and aiming at protection of important public goals) and 'rational basis test' (on issues of freedom of action in general or of contractual freedom, whereby restrictions are normally held as in conformity with the First Amendment), see Christou 2007: passim and at 31 and footnote 18, 58-9, 351 and footnote 47, 386.

Note 3. Joel Feinberg's well known distinction can be followed here, especially the qualifications he makes thematic through dealing with 'profound offenses', whereby also expressions of hate are primary candidates. Cf. Feinberg 1987: 50-96; see respectively also Herring 2008: 24. See also Christou 2007: 328-30, as to the utilization of the offense principle in the jurisdiction of the German Constitutional Court concerning hate speech and public security (to which we refer below under subchapter 3.3).

Note 4. A contradistinction to both militant-democratic and liberal account for hate crimes constitutes the peculiar "pacifistic" approach of Jacobs/Potter 2001: 144-53, inclined to promote as criminal policy the total extinction of anti-hate laws for the sake of 'integrity' and 'non-division' of society. It goes without saying that this a-political stance (insofar as political cannot but mean schism and conflict) is totally incompatible with the position supported here.

Note 5. Hate crimes are thus to be considered as "implicit endangerment offenses", as Antony Duff puts it, meaning that no concretely proven danger is required in the conduct in order for it to be punished, even if the lack of harm indicates a lesser wrong (see indicatively Ashworth 2011: 165-6).

\section{Copyrights}

Copyright for this article is retained by the author(s), with first publication rights granted to the journal.

This is an open-access article distributed under the terms and conditions of the Creative Commons Attribution license (http://creativecommons.org/licenses/by/3.0/). 